\title{
Proceeding
}

Supplementary Issue: Summer Conferences of Sports Science. First International Conference in Iraq on Sport for Peace, 4 April 2019. Baghdad Science Institute, Baghdad, Iraq.

\section{Sport consumer behaviour model: Motivators and constraints}

\author{
AYE RIZVANDI $\triangle$, FARSHAD TOJARI, ZAHEA SADEGH ZADEH \\ Department of Physical Education, Central Tehran Branch, Islamic Azad University, Tehran, Iran
}

\begin{abstract}
Sport consumers are the most important component that ensure the continuum of the sport industry. So, it is crucial to understand the factors affecting the Sport Consumer Behaviour (SCB). In this research, we tried to examine the factors that influence the attendance of sport spectators in the national league of basketball and volleyball in Iran. The results showed that internal motivators included success and wining, team support, player support, coach support, sport level support, sports support, and community support; while external motivators were comprised of promotion, media advertisement, player behaviour, excitement, aesthetic, athlete physical skills, role model. Internal constraints were lack of knowledge, lack of success, lack of interest from others, and lack of companionship. The motivators were assigned to those factors that encouraged the attendees and the constraints were considered those that prevented the attendance of fans and consumers. The external constraints and other variables were shown to have insignificant and significant effects, respectively, on sport consumer behaviour. Constrains and motivators of sport consumer behaviour can help the sport marketers for better planning and achieving greater benefits and consumer satisfaction. Keywords: Sport Consumer Behaviour (SCB); Motivators; Constraints.
\end{abstract}

Cite this article as:

Rizvandi, A., Tojari, F., \& Zadeh, Z.S. (2019). Sport consumer behaviour model: Motivators and constraints. Journal of Human Sport and Exercise, 14(5proc), S2330-S2338. doi:https://doi.org/10.14198/jhse.2019.14.Proc5.48

Corresponding author. Department of Physical Education, Central Tehran Branch, Islamic Azad University, Tehran, Iran.

E-mail: rizvandi.ie@gmail.com

Supplementary Issue: Summer Conferences of Sports Science. First International Conference in Iraq on Sport for Peace, 4 April 2019. Baghdad Science Institute, Baghdad, Iraq.

JOURNAL OF HUMAN SPORT \& EXERCISE ISSN 1988-5202

(c) Faculty of Education. University of Alicante

doi:10.14198/jhse.2019.14.Proc5.48 


\section{INTRODUCTION}

Sport and sport industry have been shown to have a meaningful impact on our society (S. H. Park, Mahony, \& Greenwell, 2010; Wann, Melnick, Russell, \& Pease, 2001). Through yielding a revenue of about $\$ 470$ billion, sport industry in the US is now two times and seven times greater in size than automobile and movies industries, respectively (S.-H. Park, Mahony, Kim, \& Do Kim, 2015; Plunkett, 2008; Bodet \& BernacheAssollant, 2011). Therefore, the significance of sport, sport-related activities, and its industry becomes tangible. As mentioned earlier, sport attendance is one of the most popular recreational activities and so, any item related to the expansion and improvement of this field gains a greater attention.

Ticket sales and sport services are critical to sport attendance and the success of professional sport organizations as they comprise $20 \%$ to $50 \%$ of the total revenue stream of spots clubs (Kim \& Trail, 2010). Hence, Sport marketers have focused their efforts on turning casual consumers into loyal consumers in order to maximize the profits (S.-H. Park et al., 2015). So, it would be useful for sport marketers to understand the factors that affect an individual's decision to purchase tickets and to attend sporting events.

Sport consumer behaviour (SCB) researches represent a sub-discipline within the academic field of sport management which evolution follows a similar trajectory as the general field of consumer behaviour. Consumer behaviour first emerged as a sub-discipline of marketing in the early 1980's drawing upon a variety of other disciplines including psychology, sociology, anthropology, economics, and general education, to investigate an individual's decision-making process (D. C. Funk, 2017; Yoshida, 2017).

\section{THEORETICAL FRAMEWORK}

In order to improve the marketing research in the field of spectatorship and revenues, researchers explored some motivational determinants such as community support, escape, interest in sport, entertainment, bonding with families, vicarious achievement, drama, bonding with friends, customer service, interest in players, role model, socialization, sport knowledge, excitement, wholesome environment, core product, social network, relationship investment quality, curiosity and knowledge, technology, clear polices, innovation, time, communication, social system, team identification, surveillance, encouragement, interest in the game, and prizes. Also, the items of constraints including car park, distance, traffic, time to get to the stadium, match time, stadium location, accessibility to public transportation, cost of going to match, weather, financial effort, win and lose, verbal aggression, physical aggressive behaviours, and boring competition (Bee \& Havitz, 2010; Bravo, Lee, \& García-González, 2016; Byon, Zhang, \& Connaughton, 2010; Fink, Trail, \& Anderson, 2002; D. Funk, Lock, Karg, \& Pritchard, 2016; D. C. Funk, 2017; D. C. Funk, Nakazawa, Mahony, \& Thrasher, 2006; D. C. Funk, Ridinger, \& Moorman, 2004; Gau \& Korzenny, 2009; W. E. Jang, Wann, \& Ko, 2018; Lock \& Heere, 2017; S.-H. Park et al., 2015; Shoham, Dalakas, \& Lahav, 2015; Tacon \& Vainker, 2017; Trail \& James, 2001; Wang, Zhang, \& Tsuji, 2011; Yoshida, 2017; Zapalac, Zhang, \& Pease, 2010).

In this term, motivators are referred to as factors that positively affect participation in an event, while the constraints are considered to be the factors that limit sport participation. According to our literature review, there are more researches focused on the motivators and less on finding the constraints in SCB. While examining the organizational citizenship behaviour (OCB) models, we only found a few researches with strong theoretical bases. Crawford Model (1991) is one of the first models of OCB adjusted by pervious researchers until now (Kim \& Trail, 2010). Trail, Robinson, \& Kim, 2008; Kim \& Trail, 2010), slight modification were made to the constraint model. 
Kim and Trail (Kim \& Trail, 2010) also claimed that internal motivators have a positive effect on attendance and is placed first in this model. When you have enough internal motivators to motivate you (the reasons to participate in a match), internal constraints start working.

If the internal constraints are strong enough to overcome the internal motivators, one would probably not attend a match. When internal constraints are subdued by external motivators, the chance of attending a match would increase. The external motivators are at the third place while external constraints are at the fourth in the process of the study model. The third and fourth step of this process are the same as the last two steps; as if motivator overcome constraints, there will be a high possibility of participation.

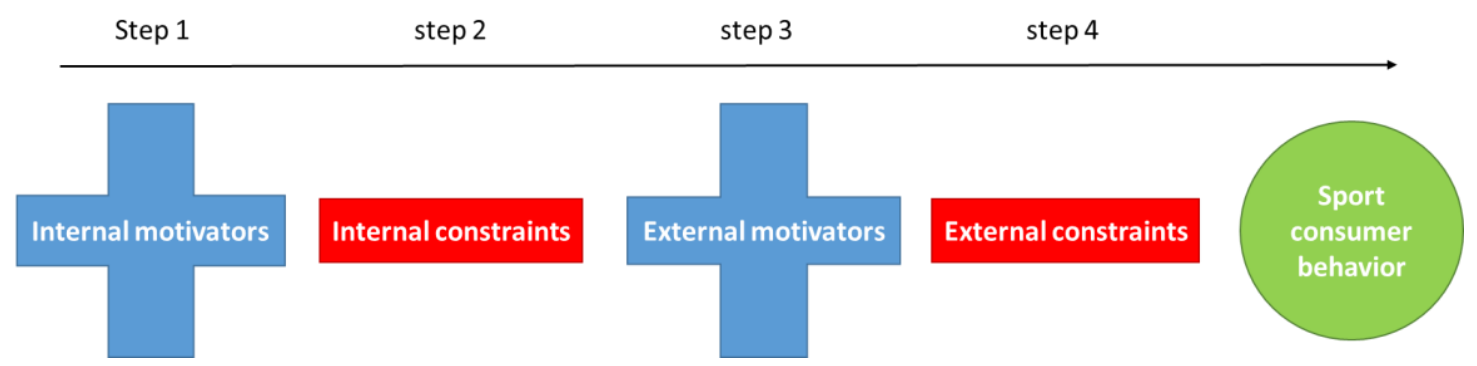

Figure 1. Motivators and constraints in SCB.

Although numerous studies have investigated a variety of factors affecting consumers' sport attendance and spectatorship, very few have examined consumer's motivators, constraints, and attendance. Regarding the importance of consumer behaviour, especially spectatorship and its influence on developing a financial support for the sports, it is necessary to examine the motivators and constraints of sport attendees. Also, according to Trail (Trail et al., 2008) and Kim et al. (Kim \& Trail, 2010), there have been no research done on the effect of cultural differences on consumers' motivation. This in turn clearly highlights the necessity of the present study.

\section{METHODOLOGY}

The participants were spectators at men's professional basketball and volleyball games. Out of 320 questionnaires randomly distributed, 220 usable questionnaires were collected yielding a return rate of $62.5 \%$. Approximately, $39.5 \%$ of the respondents were aged under 20 years, $41.5 \%$ were $21-30$ years, $14.5 \%$ were $31-40$ years, and $4.5 \%$ aged more than 40 years. The respondents appeared to be well-educated since $53.5 \%$ of our total population had at least attended some college. The participants had relatively low incomes as over three-fourths of them had an annual income of about $\$ 3600$. The sample consisted of $50.5 \%$ male and $49.5 \%$ female.

The research tool included two questionnaires of Scale for Motivators of Sport Consumption (SMSC) (Trail, 2010) to collect data of motivators, Constraints on Sport Consumption Scale (CSCS) for constraints, and Manual for the affective and behavioural measures. Items were measured using a 7-point Likert-type scale from 1 (strongly disagree) to 7 (strongly agree). The research tool was already proved of adequate internal consistency $(\alpha=0.89)$. Also, the face validity was confirmed by three professors of sport management. 
Internal motivators. This first part was comprised of nine subscales with 27 items within, measuring internal motivators. The subscales were as follows: escape, success and achievement, interest in community, interest in coach, level of sport, interest in player, socialization, and interest in sport.

Internal constraints. This second part contained four subscales with 12 items within, measuring internal constraints. The subscales were as follows: lack of knowledge, lack of success, lack of interest from others, and lack of companionship.

External motivators. This third part included seven subscales with 25 items within, measuring external motivators. The subscales were as follows: promotion, media advertisement, player behaviour, excitement, aesthetic, athlete physical skills, and role model.

External constraints. This fourth part contained of eight subscales with 35 items within, calculating external constraints. The subscales were as follows: leisure alternative, commitments, location, cost, parking, alternative sport entertainment, and participant sports.

Descriptive statistics such as mean, standard deviation, and correlation coefficient were used to analyse the demographic data from participants and research data. Confirmatory factor analysis was used to analyse the measurement model of the study and path analysis method used to confirm the theoretical model of the study and determine the beta coefficient of each factor to create the regression equation for SCB. LISREL 11 was used to run a different required statistical method. All the analyses were performed with a $95 \%$ confidence interval.

\section{RESULTS}

Descriptive statistic of research variable and the correlation between these variables are shown in table 1. The results of factor analysis and model fit indices clearly supported the measurement model of the study. The related data are presented in table 2.

Table 1. Descriptive statistic and correlation of research variable.

\begin{tabular}{|l|l|l|l|l|l|l|l|}
\hline & Mean & SD & 1 & 2 & 3 & 4 & 5 \\
\hline 1 & 4.71 & 1.05 & 1.000 & & & & \\
\hline 2 & 3.93 & 0.77 & 0.507 & 1.000 & & & \\
\hline 3 & -0.19 & 0.98 & 0.036 & -0.047 & 1.000 & & \\
\hline 4 & -1.20 & 0.75 & -0.027 & -0.078 & -0.305 & 1.000 & \\
\hline 5 & 7.42 & 1.59 & 0.090 & -0.075 & 0.106 & 0.071 & 1.000 \\
\hline
\end{tabular}

Table 2. Model fit indices.

\begin{tabular}{|l|l|l|l|l|l|l|l|l|}
\hline & $X^{2}$ & df & $p$-value & $X^{2} /$ df & RMSEA & NFI & NNFI & CFI \\
\hline Model fit indices & 8.10 & 27 & 0.05 & 0.30 & 0.032 & 0.97 & 0.98 & 0.94 \\
\hline
\end{tabular}

CFI, NFI, and NNFI values greater than 0.95 are indicators of good-fitting models (Hu \& Bentler, 1999). RMSEA and $x^{2} / d f$ values of less than 0.05 and 3, respectively, indicate good fit. REMSEA values of 0.08 or less were considered a reasonable fit and values higher than 0.10 were assigned to poor fit (Browne \& 
Cudeck, 1992). Upon comparing the values of table 2 and the standard value of each index, best fit of the measurement model of the study was affirmed (Kim \& Trail, 2010).

The results of path analysis showed that internal motivators $(T=49.45 ; \gamma=2.00 ; p=0.05)$, internal constraints ( $T=-15.98 ; \gamma=-0.72 ; p=0.05)$, and external motivators $(T=4.98 ; \gamma=0.57 ; p=0.05)$ had significant effects on consumer behaviour. The external constraints on the other hand, had insignificant effects on consumer behaviour ( $p>0.05)$. Regression equation of fitted model and model determination coefficient was as follows: $\left(R^{2}=0.94\right)$. Internal motivators $(2)-$ External constraints $(0.72)+$ External motivators $(0.57)=\mathrm{OCB}$.

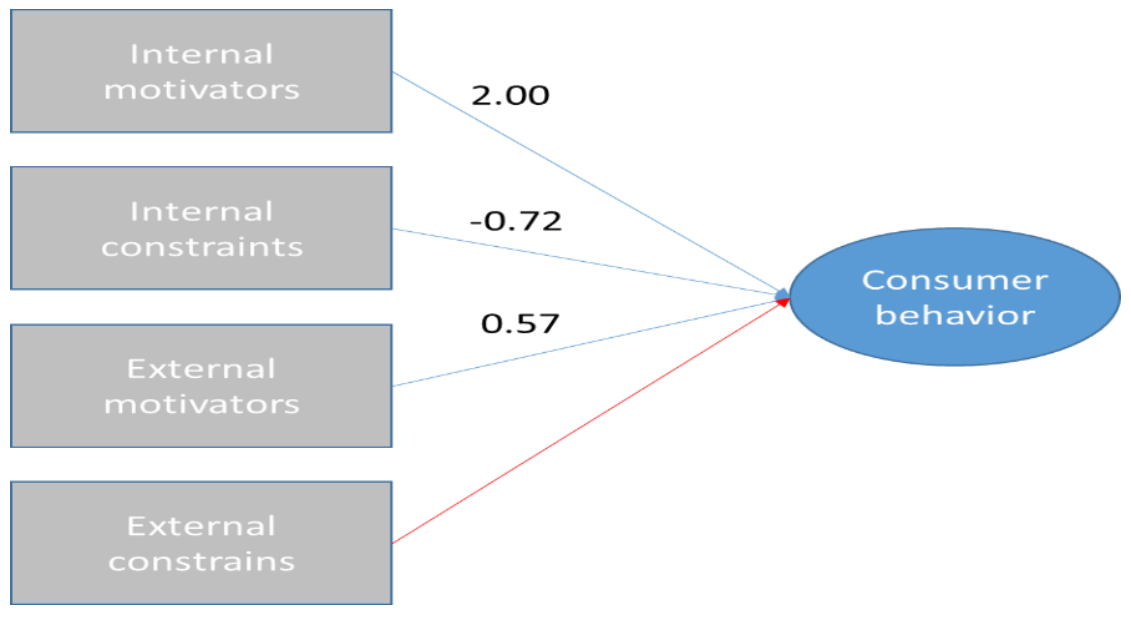

Figure 2. The diagram of factor loads coefficient.

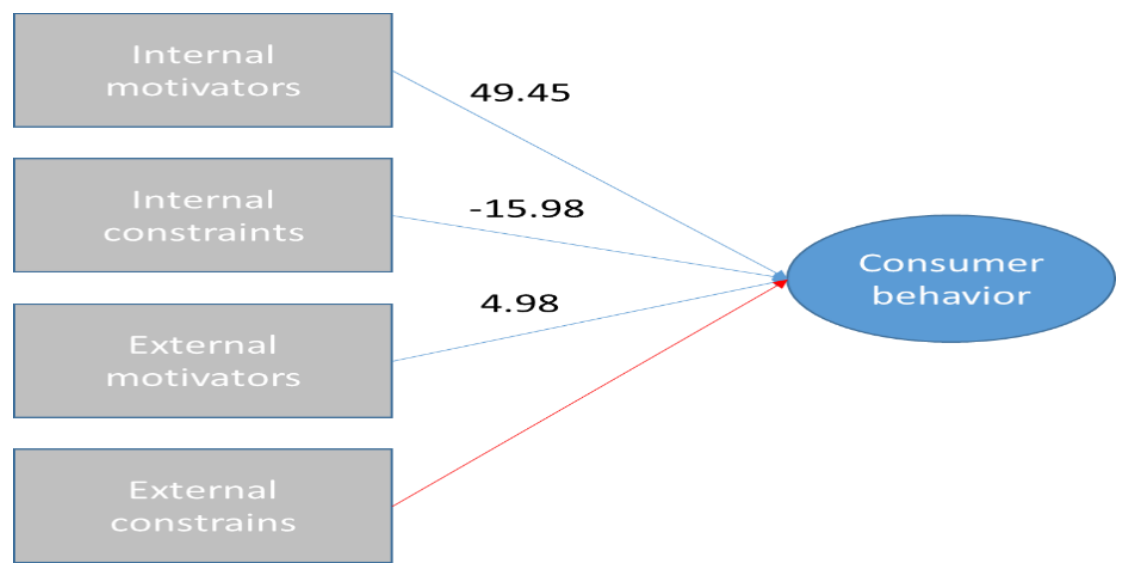

Figure 3. The diagram of t-student coefficient.

\section{DISCUSSION AND CONCLUSION}

According to the results, internal motivators were the most influential factors on SCB; since it has been shown to have the most positive effect on regression equation. Therefore, more attention should be paid to this factor in order to develop it. Success and achievement are two factors which cannot be controlled; however, they must be precisely planed out in order to increase the attendee's interest in both the team and sport. 
Accordingly, Roset and Bottenberg (2014) suggested "interest in sport" as a critical factor in sport clubs for planning their consumer's needs. Also consumers' interest in team and its related elements such as coaches, players, and so on, influences the participation of sport fans (Bravo et al., 2016). The results indicated that fans were motivated to attend a game when they already identified the team. These data supports the previous claim that team identification is a key predictor of sport consumption behaviour (D. Funk et al., 2016; D. C. Funk, 2017; E. W. Jang, Ko, Wann, \& Chang, 2017; Lock \& Heere, 2017). However, in this study and also Kim and Trail's (Kim \& Trail, 2010), internal motivator was calculated to be the most important factor predicting the consumer behaviour. As Wang et al., (Wang et al., 2011) believed that a team-dependent factor is not solely enough to predict the consumers' behaviour without considering the satisfaction. From a wider perspective, social interaction is a key determinant of sport participation (D. Funk et al., 2016; D. C. Funk, 2017; Yoshida, 2017). In this regard, Funk (D. C. Funk, 2017) has designed a framework for sport experience which could be used by the mangers of sports clubs to plan a better communication path with their consumers. In this study, the internal constraints included the lack of knowledge, lack of success, lack of interest, and lack of companionship. It is noteworthy to mention that the last two subscales were added to internal motivators by Kim and Trail (Kim \& Trail, 2010).

There are a few literature studies that examine the effect of internal constraints on SCB; as only in two studies by Crawford and Godby (Crawford \& Godbey, 1987) and Kim and Trail (Kim \& Trail, 2010), this factor has been considered as a dependant variable. There is a great variety of sports and each of them have to cover different needs and demands. According to previous results, winning or losing the game is an important reason for the study participants as they probably won't go to the next game if the team gets poor results. It could be concluded that a high team identification (E. W. Jang et al., 2017; Shoham et al., 2015) is expected in the fans of basketball and volleyball teams.

Yoshida (Yoshida, 2017) put the sport games in sport core product as he believed that it is one of the most important terms in consumer experience. Since this factor is tangible enough for the consumers to follow, managers need to pay special attention to it in order to better shape the consumer experience. In a noble study by Jang et al.(E. W. Jang et al., 2017), the concepts of winning and losing in sport were challenged. They utilized a method combining the fans team identification, game process, and the match results to evaluate the satisfaction in the fans. As mentioned earlier in this research, although losing negatively affects the consumers' attendance, a low team identification is more important since fans care more about a good game process than the results. This finding proves that there are much more determining factors involved in predicting the consumer behaviour. These factors mostly depend on the nature of the fans, games, facilities, locations and so on.

External motivators include promotion, media advertisement, player behaviour, excitement, aesthetic, athlete physical skills, and role model. According to the results, it seems that in addition to the motivators mentioned herein, satisfaction must also be considered when determining the SCB in events; as has been discussed by Jang and Tisuji (2011).

Yoshida (Yoshida, 2017) suggested the satisfaction as a key to create a good experience for the fans in order to achieve an improved plan for sport marketing. Shoham et al. (Shoham et al., 2015) found in their research that a specific level of excitement, included in the external motivators, is related to a controlled behaviour or aggression of the consumer. So, they claimed that in order to attract more fans and consumers, sport clubs must have a precise program to increase the consumer arousal to reach the highest benefits, design some program to reduce the arousal in case of aggressive behaviour, and consider another program to control the fans' arousal in the functional area. Also, results from a study by Park et al. (S.-H. Park et al., 2015) showed 
that consumer media consumption provides the individuals with a chance to seek out the sport subjects which could lead to a higher sport participation in a proper level of media consumption rather than sitting at home and watch the competition.

Meanwhile, the regression equation of internal motivators showed a greater effect compared to the external motivators. However, it must be noted that external motivators are still important since they could change upon changing the factors of place or sports. Kim and Trail (Kim \& Trail, 2010) data also affirmed that external motivators exert much less influence on consumers' behaviour. External constraints are defined as environment or social aspects that prevent or decrease the possibility of a behaviour. External factors of our research included commitments, cost, leisure alternatives, location, parking, participant sports, and alternative sport entertainment.

Bravo et al. mentioned that sport entertainment brings a wide variety of ideas together and provides lots of choices for sport consumers. Hence, sport consumers can select among their most desirable and pleasant options (Bravo et al., 2016). New sports, also known as fantasy sports, can also greatly challenge common sports since they are more adapted with the new trends and needs of sport participants (Tacon \& Vainker, 2017). It is possible that consumers in this research did not have any problem with some of the external constraints such as cost, parking, and location nor they considered them as a constraint for spectatorship. It could probably be resulted from the fact that lots of participants reside in the same city as the game was held and they did not need to pay a lot of money for communication. We suggest that the researchers examine the inter-correlation between internal motivators' subscales and study the effect of this correlation on SCB. Also, we recommend the sport managers and marketers to focus more on motivators (internal or external) because of their importance in SCB.

\section{REFERENCES}

Alexandris, K., Tsorbatzoudis, C., \& Grouios, G. (2002). Perceived constraints on recreational sport participation: Investigating their relationship with intrinsic motivation, extrinsic motivation and $\begin{array}{llll}\text { amotivation. Journal of Leisure } & \text { Research, } 34(3), \quad 233-252 .\end{array}$ https://doi.org/10.1080/00222216.2002.11949970

Bee, C. C., \& Havitz, M. E. (2010). Exploring the relationship between involvement, fan attraction, psychological commitment and behavioural loyalty in a sports spectator context. International Journal of Sports Marketing and Sponsorship, 11(2), 37-54. https://doi.org/10.1108/ijsms-11-02-2010-b004

Bodet, G., \& Bernache-Assollant, I. (2011). Consumer loyalty in sport spectatorship services: The relationships with consumer satisfaction and team identification. Psychology \& Marketing, 28(8), 781 802. https://doi.org/10.1002/mar.20412

Bravo, G. A., Lee, C., \& García-González, V. (2016). Flag football participants in Mexico and NFL

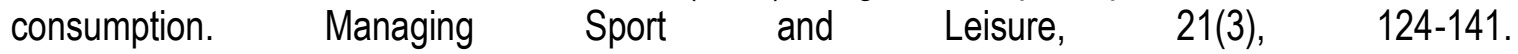
https://doi.org/10.1080/23750472.2016.1220261

Browne, M. W., \& Cudeck, R. (1992). Alternative ways of assessing model fit. Sociological methods \& research, 21(2), 230-258. https://doi.org/10.1177/0049124192021002005

Byon, K. K., Zhang, J. J., \& Connaughton, D. P. (2010). Dimensions of general market demand associated with professional team sports: Development of a scale. Sport Management Review, 13(2), 142-157. https://doi.org/10.1016/..smr.2009.07.005

Crawford, D. W., \& Godbey, G. (1987). Reconceptualizing barriers to family leisure. Leisure Sciences, 9(2), 119-127. https://doi.org/10.1080/01490408709512151 
Crawford, D. W., Jackson, E. L., \& Godbey, G. (1991). A hierarchical model of leisure constraints. Leisure Sciences, 13(4), 309-320. https://doi.org/10.1080/01490409109513147

Fink, J. S., Trail, G. T., \& Anderson, D. F. (2002). An examination of team identification: which motives are most salient to its existence? International Sports Journal, 6(2), 195.

Funk, D., Lock, D., Karg, A., \& Pritchard, M. (2016). Sport consumer behavior research: Improving our game. Journal of sport management, 30(2), 113-116. https://doi.org/10.1123//sm.2016-0028

Funk, D. C. (2017). Introducing a Sport Experience Design (SX) framework for sport consumer behaviour research. Sport Management Review, 20(2), 145-158. https://doi.org/10.1016/j.smr.2016.11.006

Funk, D. C., Nakazawa, M., Mahony, D. F., \& Thrasher, R. (2006). The impact of the national sports lottery and the FIFA World Cup on attendance, spectator motives and J. League marketing strategies. International Journal of Sports Marketing and Sponsorship, 7(3), 115-133. https://doi.org/10.1108/ijsms-07-03-2006-b011

Funk, D. C., Ridinger, L. L., \& Moorman, A. M. (2004). Exploring origins of involvement: Understanding the relationship between consumer motives and involvement with professional sport teams. Leisure Sciences, 26(1), 35-61. https://doi.org/10.1080/01490400490272440

Gau, L.-S., \& Korzenny, F. (2009). An examination of values associated with sports attitude and consumption behavior: An exploratory study. Social Behavior and Personality: an international journal, 37(3), 299-305. https://doi.org/10.2224/sbp.2009.37.3.299

Gilbert, D., \& Hudson, S. (2000). Tourism demand constraints: A skiing participation. Annals of Tourism Research, 27(4), 906-925. https://doi.org/10.1016/s0160-7383(99)00110-3

Hawkins, B. A., Peng, J., Hsieh, C.-M., \& Eklund, S. J. (1999). Leisure constraints: A replication and extension of construct development. Leisure Sciences, 21(3), 179-192. https://doi.org/10.1080/014904099273066

Jang, E. W., Ko, Y. J., Wann, D., \& Chang, Y. (2017). The relative effects of game outcome and process on fans' media consumption experiences. European Sport Management Quarterly, 17(5), 635-658. https://doi.org/10.1080/16184742.2017.1334683

Jang, W. E., Wann, D. L., \& Ko, Y. J. (2018). Influence of team identification, game outcome, and game process on sport consumers' happiness. Sport Management Review, 21(1), 63-71. https://doi.org/10.1016/i.smr.2017.03.002

Kim, Y. K., \& Trail, G. (2010). Constraints and motivators: A new model to explain sport consumer behavior. Journal of sport management, 24(2), 190-210. https://doi.org/10.1123//sm.24.2.190

Lock, D., \& Heere, B. (2017). Identity crisis: A theoretical analysis of 'team identification'research. European Sport Management Quarterly, 17(4), 413-435. https://doi.org/10.1080/16184742.2017.1306872

Park, S.-H., Mahony, D. F., Kim, Y., \& Do Kim, Y. (2015). Curiosity generating advertisements and their impact on sport consumer behavior. Sport Management Review, 18(3), 359-369. https://doi.org/10.1016/i.smr.2014.10.002

Park, S. H., Mahony, D. F., \& Greenwell, T. C. (2010). The measurement of sport fan exploratory curiosity. Journal of sport management, 24(4), 434-455. https://doi.org/10.1123/ism.24.4.434

Plunkett, J. W. (2008). Plunkett's Sports Industry Almanac 2009: Plunkett Research, Ltd.

Shoham, A., Dalakas, V., \& Lahav, L. (2015). Consumer misbehavior: Aggressive behavior by sports fans. Services Marketing Quarterly, 36(1), 22-36. https://doi.org/10.1080/15332969.2015.976506

Tacon, R., \& Vainker, S. (2017). Fantasy sport: a systematic review and new research directions. $\begin{array}{llll}\text { European Sport } \quad \text { Management } & \text { 458-589. }\end{array}$ https://doi.org/10.1080/16184742.2017.1347192

Trail, G. T., \& James, J. D. (2001). The motivation scale for sport consumption: Assessment of the scale's psychometric properties. Journal of sport behavior, 24(1). 
Trail, G. T., Robinson, M. J., \& Kim, Y. K. (2008). Sport consumer behavior: A test for group differences on structural constraints. Sport Marketing Quarterly, 17(4), 190.

Wang, R. T., Zhang, J. J., \& Tsuji, Y. (2011). Examining fan motives and loyalty for the Chinese Professional Baseball League of Taiwan. Sport Management Review, 14(4), 347-360. https://doi.org/10.1016/i.smr.2010.12.001

Wann, D. L., Melnick, M. J., Russell, G. W., \& Pease, D. G. (2001). Sport fans: The psychology and social impact of spectators: Routledge.

Yoshida, M. (2017). Consumer experience quality: A review and extension of the sport management literature. Sport Management Review, 20(5), 427-442. https://doi.org/10.1016/j.smr.2017.01.002

Zapalac, R. K., Zhang, J. J., \& Pease, D. G. (2010). Understanding women's collegiate volleyball spectators from the perspectives of sociodemographics, market demand and consumption level. International Journal of Sports Marketing and Sponsorship, 11(4), 50-73. https://doi.org/10.1108/ijsms-11-04-2010-b005

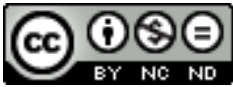

This work is licensed under a Attribution-NonCommercial-NoDerivatives 4.0 International (CC BY-NC-ND 4.0). 